\title{
Profile of Speaking Activities of Senior High Schools (Teachers' Experiences)
}

\author{
Sulastri Manurung \\ English Education Department \\ University of Riau Kepulauan \\ lastri.manru@yahoo.com
}

\begin{abstract}
This study aimed at describing the whole speaking activities in teaching learning English for Senior High Schools in Batam based on teachers' experiences by giving an open questionnaire and then categorizing the data collected using continuous comparison technique. This research is a descriptive qualitative research with naturalistic approach. The research setting is in Batam. The key instrument of this research is the researcher herself. The data are gathered through distributing questionnaire. The data are in the form of words, phrases and sentences. The data gathered were selected based on the type of the activity, named the categories and broke the data into some categories which then would be shown in tables. The result of the research shows that speaking activities for senior high schools in Batam can be divided into six types in general then broke down into 19 categories. Speaking activity in monolog was the most frequently used by teachers and dominated the activity. It occurred 36 times in teaching and learning process.
\end{abstract}

Keywords: profile, speaking, teachers' experiences

\section{INTRODUCTION}

For many people, speaking skill is the most important aspect of language and the success of communication is measured on how the speakers carry out the conversation. Therefore, speaking is a very crucial thing in teaching learning language especially teaching learning English whether as a second language or foreign language, as many people have known that English has become one of international language.

Realizing how important speaking is in our daily situation, no matter what and where we are, is the main reason for the writer for choosing this topic. The writer's goal is to describe teaching learning activities of speaking class and describes any strategies used by English teachers in teaching speaking for Senior High School students in Batam. However, speaking class activities vary in each class. The activities are various depending on all components involve that support the teaching learning activities. Each teacher performs 
different style in their teaching although they teach the same materials. Likewise the students' performance in English speaking may different one another even though they are taught the same material. This diversity will be explained clearly that is packaged in a profile.

This thesis was presented in a form of a profile of speaking class which is performed by English teachers who are currently teaching in Senior High Schools Batam. The thesis describes an investigation that was conducted over the course of the teachers' speaking class. The research was carried out in classrooms of grade X, XI and XII SMA Batam where English is taught as a foreign language. The profile is influenced by all components such as students, material, teachers, method, time, place, facility and the environment. (1) Students' profile is influenced by external and internal factors; (2) Materials which are well prepared before hand by the teachers and fit for the students will influence the profile of the class; (3) Teachers' role in creating an effective teaching learning activity is required as it will influence the teacher, students and the teaching learning activity; (4) Methods and techniques used by the teachers in teaching speaking class affect the success of the language teaching activity. The approach or strategy is actualized with the methods and the methods are actualized with the techniques and tactics; (5) Time is also important component in teaching speaking class. Before preparing material and appropriate method of teaching, teachers need to consider the time of their teaching; (6) Place or the physical environment in which the language teaching activities are performed and the social dimension of the environment also contribute for the development of the speaking skill; (7) Facility also gives contribution to create an effective teaching speaking. The absence of the facility certainly will affect the method or teaching strategy of the teacher and (8) Infrastructure gives a great contribution to the teaching learning. In order to reach the goal of the teaching learning, classrooms or school should equipped with sufficient infrastructure such as electricity, classrooms, etc.

The focus of this research is to describe the profile of various teaching activities and strategies used by teachers to promote students' speaking skill. Therefore, this study seeks the answers to the following questions:

1. How is the profile of speaking activities of Senior High Schools Batam?

2. What strategies do the teachers use in teaching learning English speaking for Senior High Schools in Batam?

Besides knowing several types of speaking activities, we need to know about the functions of speaking in human interaction. According to Brown and Yule in Richard (2008) there are three functions of speaking. 


\section{- Talk as Interaction}

The first is interaction in which the speakers as people in the conversation. The speakers exchange information, greetings, engage in small talk and chit chat through a conversation that create a social interaction and require two-way participation casually or formally.

\section{- Talk as Transaction}

The second type is transaction which focuses on what is said and done. This type of speaking is intended to give or obtain information but grammatical accuracy is not the priority. It is mostly exist when the speakers are discussing some problems, sharing opinions and ideas, etc.

\section{- Talk as Performance}

The third is performance which shows the transmission of information. Speaking is frequently presented as monologue rather than dialog which use more formal language. It also reflects organization and sequencing and monitored for the accuracy.

In language teaching learning, teachers as instructor needs to know the characteristic of students and the teachers themselves in order to provide the best strategies for teaching English especially speaking as integrated in all language aspect. Knowing the students' characteristics will help teachers to prepare the students, material and best strategies to improve the output of the language learning. Teachers need to consider the following:

\section{Connection of Students' Characteristics and Learning Process}

Colorado (2007) states that English language learners (students) when learning English speaking in the classroom come with wide variety of language literacy skills and background of knowledge.

\section{Connection of Teachers' Characteristics and Teaching Learning Process}

Some researches show that there is a significant connection between teachers' characteristics and teaching learning process. An effective teaching learning is absolutely related to effective and qualified teacher and teaching. 


\section{METHODOLOGY}

This research is a descriptive qualitative research with naturalistic approach. This means the researcher studies things in natural way, setting, and attempting to make sense or interprets the data carefully. It is called a descriptive because in this research, the researcher describes clearly strategies used by English teachers in Batam for teaching English as a foreign language particularly in speaking. The data are conveyed in paragraphs without require any measurement. Therefore, the following (participants, objects, setting, instrument, data collection and analysis technique) will be identified.

\section{- Participants}

The participants of this research are all English teachers who unite in deliberation of English subject teachers (MGMP in Indonesian). The teachers are teaching in different schools, state schools and private schools, which located in different area from the hinterland to the centre of the city.

\section{- Object}

The object of the research is the speaking class activity. The writer observed the events happen in the classroom to gather the data and information about the strategies used by the teachers.

\section{- Setting}

The research took place in two classes of three different schools taught by different teachers. The investigation was held during the teaching speaking class.

Primary data were taken by giving open questionnaires. The questionnaires are distributed to participants to get respond for categorizing. The researcher also observed the classroom activity during the speaking class in order to gather more accurate data. This observation and questionnaires aim to gather information in teaching speaking activity that involve teacher, student, material, method, facility, time, place, environment. Technique of analyzing the data is by using continuous comparison or constant comparative. The researcher used categorized analysis by gathering the data, categorize, present the data in table and finally analyze the data. 


\section{RESULTS}

In this research, the writer got 83 data about speaking activities in Senior High School Batam based on teachers' experiences which are categorized into six categories based on types of activity; they are monolog, dialog, question and answer, discussion, debate and interview. Monolog activities are explained from three different aspects, method, material and media. Dialog activities involve media, method, material and place. Question-answer activities involve method and material. As the first stage, the writer categorizes the activities into six types of activities. Speaking activities of Senior High Schools Batam in monolog consist of 30 data which are broken into six categories, they are method (19 data), material (9 data), and media (2 data). The 19 data based on method use in monologs categorized into five categories which consist of teacher-student direction (4 data), student-teacher direction (6 data), student-centered (4 data), and presentation (5 data).

Speaking activities in dialog consist of 36 data which are categorized into 4 categories, namely media, method, material and place. The first category is based on media usage (1 data), based on teachers' method (26 data), based on material ( 7 data) and based on place (2 data). Dialog activities based on teachers' method are categorized into five aspects such as teacher-student direction (9 data), student-centered (5 data), using game (1 data), acting ( 2 data), and role play (7 data). Speaking activities in question-answer consist of 11 data are categorized into two related aspects; they are method ( 8 data) and material ( 3 data). On the other hand, the other activities such as discussion (3 data), debate (2 data) and interview (1) are presented individually.

\section{DISCUSSION}

\section{Speaking Activities in Monolog Based on Teacher-Student Direction}

From the questionnaires distributed and depth interview, teachers explained two speaking activities in monolog by using teacher-student method. The four activities show teacher-centered approach to studies. Teachers and students are not engaged in communicative interaction therefore they are categorized as monolog. However, starting the speaking activity by introducing the picture in English and requiring the students to memorize an English song regarded as creative teaching strategies. 


\section{Speaking Activities in Monolog Based on Student-Teacher Direction}

Teachers trigger the students to speak by providing pictures and give more opportunities for them to practice. Describing pictures requires longer explanation. This activity demands students to explore their English practices which will help them to enhance their English. After visiting a certain place such as zoo, public places, or object tourism, students tell about their experience during their visit and teacher guides them by giving some questions. Teacher required the students to memorize vocabulary.

\section{Speaking Activities in Monolog Based on Student-Centered}

Students take more participation during the teaching learning activities by demonstrating group project and introducing themselves. Phrases "siswa bercerita tentang isi film" (students tell about the film) (data no.4) shows speaking activity by story retelling. Students retell the important details of stories and stress the focus on their comprehension about the content of the film.

\section{Speaking Activities in Monolog Using Presentation}

Speaking activities such as describing, telling procedure and explanation which belong to monolog are presented by using presentation.Storytelling which is usually told by someone. Students also demonstrate a certain procedure on how to operate a machine such as washing machine, computer, etc, using presentation.

\section{Speaking activities in Monolog Based on Material}

Teachers tell the story for the students and ask them to retell about it. This activity helps students both in speaking skill and listening and also helps the teachers to attract the students' attention on the subject. However, using story as the source of material in speaking activity is more suitable for young learners.

\section{Speaking Activities in Monolog Using Media}

Teacher provides some pictures which relevant with the topics. By using the pictures, students may make some sentences, tell the sequence of a story or describe the pictures by their own sentences. Therefore, students will be able to present a monolog in front of their friends or teacher. 


\section{Speaking Activity in Dialog Using Media}

Teacher accommodates the students for speaking activity by providing some pictures contain various types of expressions, they might such as expressions of anger, sympathy, sadness, etc. The next stage, teacher assigns the students to write some words, phrases or sentences. Finally, teacher encourages the students to practice in dialog more freely. Teacher also gives motivation and encouragement for students during the exercise.

\section{Speaking Activities in Dialog Based on Teacher-Student Direction}

Based on the researcher's experience in her language teaching, after giving some examples of the dialog, choose interesting topic and prepare examples of conversations, students will practice dialog with their teacher and other students. However, such dialog activity does not provide a significant development on students' speaking skill as they simply memorize the script dialog but are not able to communicate naturally.

\section{Speaking Activities in Dialog Based on Student-Centered}

Teacher gives chance to the students to create their own dialog based on the topic they like. Students may create their own topic and therefore they may make their own dialog based on their interest. Moreover, giving opportunity for students do create their own topic and dialog will bring pleasantness for students. Therefore, students will be more interested and confidence during the dialog.

\section{Speaking Activity in Dialog Using Games}

These activities purpose to break down barriers between teachers-students or studentsstudents. The following chart shows speaking activity in dialog using communicative game.

\section{Speaking Activities in Dialog Based on Acting from Script}

Teacher provides the topic and students have to create their own script. By using this method, students automatically use facial expression and gesture based on the dialog on the script. 


\section{Speaking Activities in Dialog Using Role Play}

In role plays, the teacher assigns students and put them into situations that resemble real situation. Students pretended to be someone in different social context and have different role.

\section{Speaking Activities in Dialog Based on Material}

Choosing the appropriate material for dialog for students will make the dialog success and enable the students to communicate in English well.

\section{Speaking Activities in Dialog Based on Place}

In teaching dialog, teachers also consider the setting where dialog may take place. Classroom can be considered as one of the most appropriate and efficient for students to practice their speaking

\section{Speaking Activities Using Question Answer}

During this activity, students will excavate their ability to ask and to answer the questions directly. Teacher gives some questions to the students about the expressions being taught then students give respond that deals with it.

\section{Speaking Activities in Question Answer Based on Material}

Expressing opinion is an effective tool for asking answering questions in senior high school. In order to increase their critical thinking, students should be trained to express what they think or feel about something. Therefore, material selection for question answer needs to be taken into teacher's consideration before doing the activity.

\section{Speaking Activities in Discussion}

Through discussion, teacher encourages the students to ask questions, communicate their ideas and thoughts, arguing or supporting a certain case, even dare to take side in a discussion. 


\section{Speaking Activities in Debate}

The debate is started by the first speaker of the affirmative side followed by rebuttal of the first speaker of negative side. Likewise the second speaker of the affirmative side gives rebuttal for the first speaker of the negative side and supports his team with evidence. Next speaker of each team does the similar thing. At the end of the debate, each team sends its representative called as reply speaker and gives affirmation why their team deserves to win.

\section{Speaking Activity in Interview}

Interview means when one person has some information but other person does not have. Interview enables students to exchange the information that will helpful to enhance students' speaking skill.

The teachers responses toward the questionnaires were transcribed were broken into six categories. Among the six types of the activities, dialog dominated the speaking activities. Most of the dialogs are directed from teacher to students and student-centered that focuses on students as participants. Other dialogs include role play, acting from script and game. Some teachers also develop the dialog based on media usage, material and place where the dialog takes place. The second dominated category is monolog. In monolog, some activities are directed from teacher to students through telling stories, introducing and telling the pictures to the students, teaching English songs and obligate the students to memorize them. Most of the activities in monolog involve students and require them to describe pictures, sing English songs, retells the story based on their experiences in visiting a certain place or films they have watched. Other monolog activities are also held by using presentation, while others also develop based on the material. On the other hand, question answer is not too dominating the activities. Only a few teachers include discussion, debate and interview as speaking activities in teaching learning English. Among the 83 data, only two of them are held in debate, three activities in discussion and one activity in interview.

The implication above suggests that teachers need to promote students' critical thinking through various activities such as debate, discussion and interview. Through these activities, students are stimulated to think critically and logically. Although the dialog and monolog are still conducted as speaking activity, teachers need to boost students' speaking creative spark by involving them in natural dialog or monolog instead of memorizing the 
dialog script. Teachers also need to modify the activities that lead the students to be able to speak interactively. In order to increase critical thinking of the students, teachers need to consider types of speaking activities that suitable for the students' level. Teachers also need to reduce their role during the speaking activity but rather focus on the role of the students' activity. This can be done by using creative teaching strategies.

\section{REFERENCES}

Colorado, Colorin. (2007). The diversity of English language learners. Retrieved from: http: //www.colorincolorado.org/. Accessed on December 7, 2014.

Richard, J. (2008). Teaching speaking theories and methodologies. 